\title{
Pancreatic Histological Profile on the Efficacy of Extract of Etlingera calophrys (K. Schum) A.D. Poulsen Stem against Streptozotocin-Induced Diabetes in Diabetic Model Rats
}

\author{
Adryan Fristiohady 1(D), Mesi Leorita ${ }^{1}$, Fadhliyah Malik ${ }^{1}$, Andi Sri Wahyuni Thamrin ${ }^{1}$, Muhammad \\ Ilyas Y ${ }^{1}$, Wahyuni ${ }^{1}$, La Ode Muhammad Julian Purnama ${ }^{1}$ (D), Idin Sahidin 1,* (D) \\ 1 Faculty of Pharmacy, Halu Oleo University, Kendari 93232 South East Sulawesi, Indonesia \\ * Correspondence: adryanfristiohady@uho.ac.id;
}

Scopus Author ID 55345515600

Received: 15.08.2020; Revised: 5.09.2020; Accepted: 7.09.2020; Published: 10.09.2020

\begin{abstract}
Diabetes Mellitus (DM) is a metabolic disorder characterized by hyperglycemia that leads to oxidative stress. Antioxidant agents can be used to reduce oxidative stress. Olae (Etlingera calophrys) is one of the plants that exhibit antioxidant properties. Thus, this study aims to investigate the hypoglycemic and protective effect of Olae in the pancreatic of diabetic model rats. The anti-diabetic effect of Olae stems extracts conducted by measuring the blood glucose levels and histological examination of the pancreatic organ in diabetic model rats. All treatment groups with Olae stems extract decreased blood glucose levels compared to the negative control $(p<0.05)$. The dose of $250 \mathrm{mg} / \mathrm{kg} \mathrm{BW}$ provided higher activity than the 200; 150 ; and $100 \mathrm{mg} / \mathrm{kg} \mathrm{BW}$. Cell numbers of islets showed that Olae stems extract dose of 100; 150; 200; and $250 \mathrm{mg} / \mathrm{kg}$ BW increased, compared to normal and negative groups. In conclusion, Olae stems extract provides an anti-diabetic effect with a protective and repairing effect toward islets of Langerhans.
\end{abstract}

Keywords: Olae; Etlingera calophrys (K. Schum) A. D. Poulsen; antidiabetic; antioxidant.

(C) 2020 by the authors. This article is an open-access article distributed under the terms and conditions of the Creative Commons Attribution (CC BY) license (https://creativecommons.org/licenses/by/4.0/).

\section{Introduction}

Diabetes Mellitus (DM) is a metabolic disorder of carbohydrate, fat, and protein resulting in a defect in insulin secretion, insulin sensitivity, or both. Hyperglycemia or increased blood glucose levels in circulation is characteristic of DM. [1]. WHO (World Health Organization) stated that $8.5 \%$ of adults (18 years and older) had diabetes in 2014, and was a direct cause of 1.6 million deaths in 2016 [2]. DM is a major problem worldwide and estimated around 424.9 million adults with DM [3].

Hyperglycemia in diabetic patients increases the production of mitochondrial reactive oxygen species (ROS), resulting in oxidative stress [4]. ROS is produced in many pathways, such as increased polyol pathway, increased formation of advanced end-products (AGEs), and protein kinase $\mathrm{C}$ (PKC) activation [5]. Oxidative stress causes apoptosis dysfunction and impairment in pancreatic $\beta$-cells, resulting in necrosis [6]. Besides, oxidative stress leads to multiorgan damage and triggers complications [7].

Antioxidant plays a vital role in the treatment of diabetes mellitus (DM). The antioxidant can neutralize free radicals, including ROS, and suppress oxidative stress during 
hyperglycemia [8]. The terrestrial natural products become the source of antioxidants, such as plants of the genus Etlingera. The previous study conducted showed that several species from the genus Etlingera exhibit high antioxidant activity [9]. One of the genus Etlingera, Etlingera elatior (Jack) R.M Smith, has high antioxidant activity that suppresses oxidative stress and reduces blood glucose levels in the diabetic model rats [10,11].

Etlingera calophrys (K. Schum) A. D. Poulsen or locally in Southeast Sulawesi, known as Olae that exhibits high antioxidant activity from its stems [12]. Genus Etlingera contains flavonoids and tannins. Flavonoids are natural antioxidant agents that help DM complications involving oxidative stress such as neuropathy and renal and liver impairment [9]. On the other hand, tannins act as astringent on the surface of the small intestine's lining, thus inhibiting the absorption of glucose, resulting in decreased blood glucose levels.

Olae (E. calophrys) stems are suspected of having an antioxidant activity which can decrease blood glucose levels, due to distinct species in the same genus that usually provide similar activity such as E. elatior provides anti-diabetic activity [10,11]. Also, there are no studies reported yet the effect of Olae, primarily the stems in decreasing blood glucose levels. Thus, this study aims to investigate the effect of Olae or E. calophrys stems in decreasing blood glucose levels towards the diabetic model rats.

\section{Materials and Methods}

\subsection{Plant collection, determination, and extraction.}

A total of $20 \mathrm{~kg}$ of Olae (Etlingera calophrys (K. Schum) A. D. Poulsen) stems collected in Punggaluku, South Konawe, Southeast Sulawesi. The sample collected was determined in the Biological Laboratory of Faculty of Mathematics and Natural Science of Halu Oleo University. The collected sample was cleaned with running water, wetly sorted, and dried under sunlight obtained $1.5 \mathrm{Kg}$ of powder.

Olae stems $(1.5 \mathrm{Kg})$ were macerated using $96 \%$ ethanol $(4.5 \mathrm{~L})$ for $3 \times 24$ hours. The extract collected then concentrated using a rotary vacuum evaporator $\left(50^{\circ} \mathrm{C}\right)$ and obtained 118.3 g concentrated extract $(7.8 \%)$.

\subsection{Extract characterization.}

\subsubsection{Solubility of extract.}

Extract $(5 \mathrm{~g})$ was put in a volumetric flask and added $100 \mathrm{~mL}$ of water-saturated chloroform. The flask then was shaken for 6 hours and left for 18 hours. After that, the filtrate was evaporated on the pre-weighed evaporating dish at $105^{\circ} \mathrm{C}$ until the weight is constant. Solubility extract in water is presented in percentage (\%) [13].

\subsubsection{Ethanol solubility of extract.}

Extract $(5 \mathrm{~g})$ was put in a volumetric flask and added $100 \mathrm{~mL}$ of ethanol. The flask then was shaken for 6 hours and left for 18 hours. After that, the filtrate was evaporated on the preweighed evaporating dish at $105^{\circ} \mathrm{C}$ until the weight is constant. Solubility extract in ethanol is presented in percentage [13]. 


\subsubsection{Moisture content determination.}

Extract $(10 \mathrm{~g})$ was put in a pre-weighed evaporating dish and heated at $105^{\circ} \mathrm{C}$ for 5 hours and weighed until constant. Moisture content is stated in percentage (\%) [13].

2.2.4. Ash content determination.

Extract $(2 \mathrm{~g})$ was put in pre-weighed closed silica-crucible. It was flamed $\left(700-800^{\circ} \mathrm{C}\right)$ until the charcoal ran out, then cooled down and followed by weighing the crucible [13].

\subsection{Phytochemical screening.}

The extract was chemically screened to detect alkaloids, flavonoids, tannins, saponins, quinines, and terpenoids. The reagents used to detect them were Mayer, $\mathrm{Mg}+\mathrm{HCl}, \mathrm{HCl} 2 \mathrm{~N}$, FeCl3, Liebermann-Buchard, and $\mathrm{NaOH} 1 \mathrm{~N}$, respectively [14].

\subsection{Animals.}

The animal used is male rats (Rattus norvegicus) that had been acclimatized for seven days in a controlled environment. They were fed with a regular diet at 08.00 and 17.00 , and water ad libitum. Animals involved in this study were conducted under the ethical committee of Halu Oleo University (No. 737/UN29.20/PPM/2019).

\subsection{Experimental design.}

On day 8, animals were divided into seven groups $(n=4)$ : Group I, Group II, Group III, Group IV, Group V, Group VI, and Group VII. Group II-VII were starved overnight before induced with a streptozotocin (STZ) dose of $40 \mathrm{mg} / \mathrm{mL}$ intraperitoneally. Animals were returned in the cage and fed the regular diet and water ad libitum. On day 10, blood was collected to measure the glycemic status. On day 11, each group was treated for seven days, as follows:

Group I: non-induced group and $0.5 \% \mathrm{Na} \mathrm{CMC} \mathrm{(as} \mathrm{normal} \mathrm{control)}$

Group II: Metformin (as positive control)

Group III: $0.5 \% \mathrm{Na}$ CMC (as negative control)

Group IV: Etlingera caloprhrys extract dose of $100 \mathrm{mg} / \mathrm{kg} \mathrm{BW}$

Group V: Etlingera caloprhrys extract dose of $150 \mathrm{mg} / \mathrm{kg} \mathrm{BW}$

Group VI: Etlingera caloprhrys extract dose of $200 \mathrm{mg} / \mathrm{kg} \mathrm{BW}$

Group VII: Etlingera caloprhrys extract dose of $100 \mathrm{mg} / \mathrm{kg} \mathrm{BW}$

On day 18 , blood was drawn via a lateral vein $(1 \mathrm{~mL})$ and centrifuged for 10 minutes at $3000 \mathrm{rpm}$. Blood collected were combined with glucose reagent GOD FS (DiaSys ${ }^{\circledR}$ ) and measured under photometer $5010_{\mathrm{v} 15+}(\lambda 546 \mathrm{~nm})$.

The animals were sacrificed for harvesting pancreatic organ. The pancreatic organ was cleaned with $0.9 \% \mathrm{NaCl}$ and fixated with $10 \%$ buffer neutral formalin (BNF) for 48 hours. The organ was then put in tissue cassette and dehydrated with an increased concentration of alcohol $(70 \%, 80 \%, 90 \%$, and $95 \%)$ and followed by clearing with using Xylol I and Xylol II and infiltrated with paraffin wax, thus forming blocks. The blocks were cut thickness of 4-5 $\mu \mathrm{m}$ with a microtome. The sections were put in object glass and incubated with an incubator $\left(37^{\circ} \mathrm{C}\right)$ for 24 hours. After that, sections were deparaffinated and rehydrated, followed by staining with hematoxylin and eosin (HE). Then, sections were examined and photographed by using a light microscope (magnification $400 \mathrm{x}$ ). 


\subsection{Statistical analysis.}

Blood glucose levels were analyzed statistically using SPSS Statistics 20.0 (IBM Inc., USA). Data were analyzed by using One Way ANOVA, continued with post hoc LSD if data were normally distributed and were continued by Kruskal-Wallis if data were not normally distributed. The significant difference indicated with value $\mathrm{p}<0.05$.

\section{Results and Discussion}

\subsection{Extract characterization.}

Olae (Etlingera calophrys (K.Schum) A. D. Poulsen) stems extract characterization aims to ensure the extract used in the study. The extract should meet the standards required. The result of the extract characterization is presented in Table 1.

Table 1. Characterization Extract of Olae (Etlingera calophrys (K.Schum) A. D. Poulsen) stems

\begin{tabular}{l|l|l} 
& Standard & Results \\
\hline Water Solubility of Extract & The higher the solubility level of the extract is good & $26.7 \%$ \\
\hline Ethanol Solubility of Extract & The higher the solubility level of the extract is good & $38 \%$ \\
\hline Moisture Content & $\leq 10 \%$ & $10 \%$ \\
\hline Ash Content & $\leq 7 \%$ & $26.7 \%$
\end{tabular}

Solubility extract in water and ethanol are conducted to determine the phytochemicals detected in solvents from the extract. Besides, it helps in choosing the right solvent [13]. Moisture content aims to determine the amount of water contained in the extracts. Excess amounts of water in extract accelerate the growth of microbes and decomposition [13]. Thus, the standard required for moisture content is less than $10 \%$ [13]. On the other hand, ash content conducted aims to determine the levels of inorganic minerals contained in the extract $[13,14]$.

\subsection{Phytochemical screening.}

Phtochemical screening is conducted to determine phytochemicals contained in Olae (Etlingera calophrys) stems, thus provide the most likely compounds that playing roles in decreasing blood glucose levels [15,16]. Phytochemicals of Olae stems are presented in Table 2. According to results, Olae contains flavonoids, tannins, and terpenoids.

Table 2. Phytochemical Screening of Etlingera calophrys.

\begin{tabular}{l|l} 
Phytochemical & Result \\
\hline Alkaloids & - \\
\hline Flavonoids & + \\
\hline Saponins & - \\
\hline Tannins & + \\
\hline Terpenoids & + \\
\hline Quinones & - \\
\hline$*+=$ positive; - = negative &
\end{tabular}

\subsection{Anti-diabetic effect of olae (Etlingera calophrys) stems to extract.}

Anti-diabetic activity of Olae (E. calophrys) stems extract conducted to investigate the hypoglycemic effect of Olae stem extract in diabetic model rats. Rats were induced with the Streptozotocin (STZ) dose of $40 \mathrm{mg} / \mathrm{mL}$, resulting in diabetic model rats. STZ is forming reactive free radicals that damage cell membranes, thus $\beta$-cell pancreatic disrupted in producing insulin $[17,18]$. 


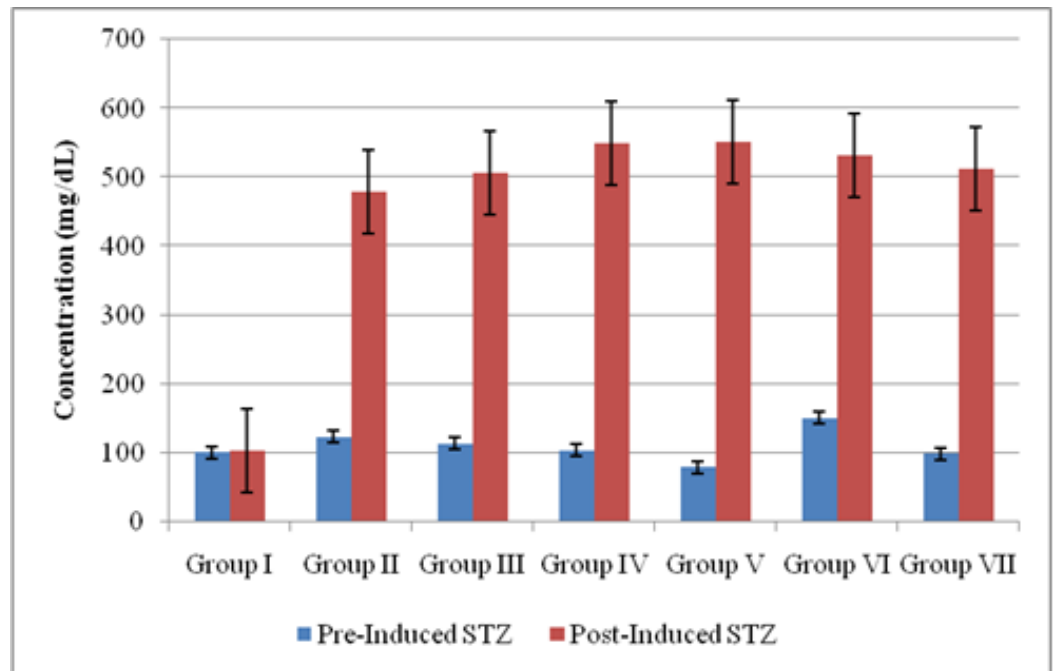

Figure 1. Effect of STZ (Streptozotocin) in Inducing Blood Glucose Levels of Rats in mean \pm SD.

The examination of blood glucose levels was conducted pre- and post-induction with STZ $40 \mathrm{mg} / \mathrm{mL}$. All groups experienced increasing blood glucose levels post-induction, except group I or known as the normal group. Figure 1 is presenting the condition of rats.

Post-treatment in each group demonstrated decreased blood glucose levels of rats' post administrating with extract of Olae (E. calophrys) stems. Figure 2 is presenting the results.

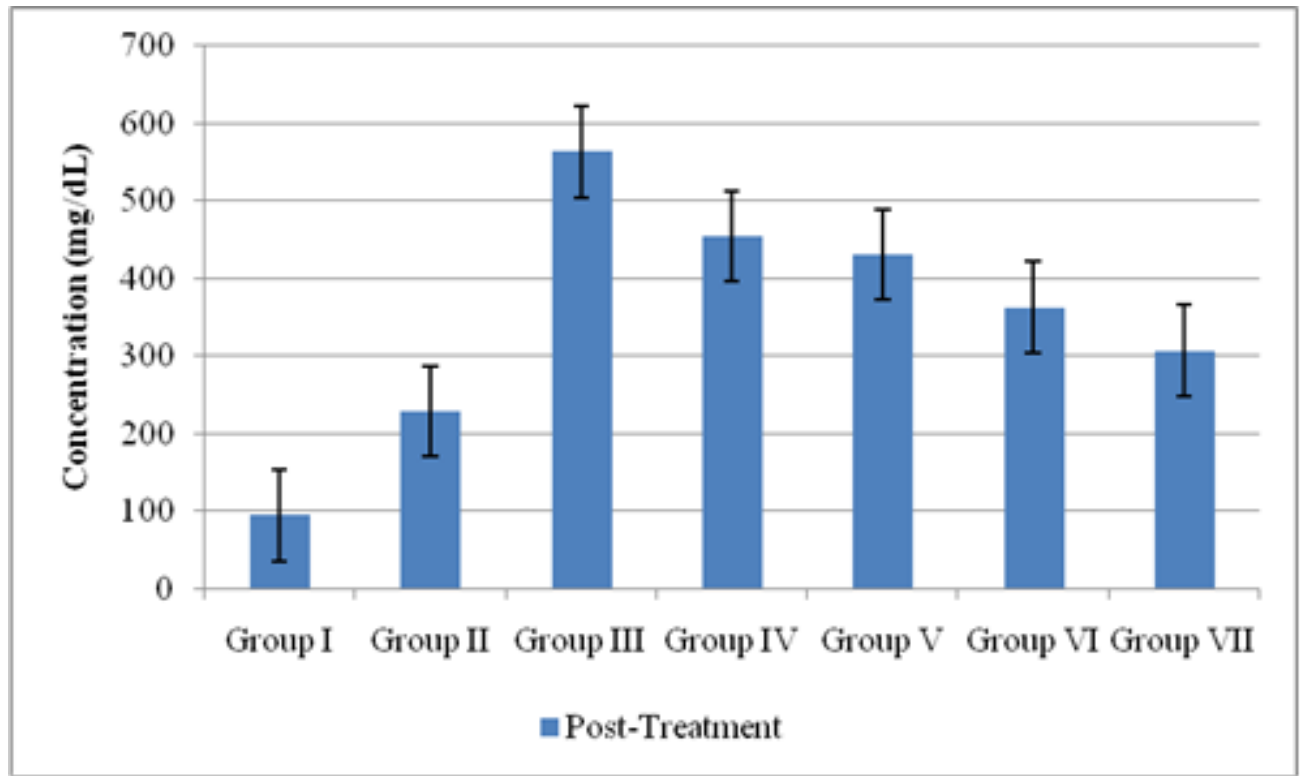

Figure 2. Effect of Olae Stems Extract in Decreasing Blood Glucose Levels of Rats in mean $\pm S D(n=4)$. (Group $\mathrm{I}=$ normal control; group II = metformin dose of $500 \mathrm{mg} / \mathrm{KgBW}$; group III $=0.5 \% \mathrm{Na} \mathrm{CMC}$; Group IV = extract dose of $100 \mathrm{mg} / \mathrm{KgBW}$; Group V = extract dose of $150 \mathrm{mg} / \mathrm{KgBW}$; Group VI = extract dose of 200 $\mathrm{mg} / \mathrm{KgBW}$; Group VII = extract dose of $250 \mathrm{mg} / \mathrm{KgBW}$.

The effect of Olae (E. calophrys) stems extract in decreasing blood glucose levels by comparing with group II (positive control) and Group III (negative control). All treatment groups (group IV-VII) demonstrate a significant decrease in blood glucose levels $(p<0.05)$ compared to group II and Group III. Increasing dose of extract demonstrated better effect in decreasing blood glucose levels into $306.4 \mathrm{mg} / \mathrm{dL}$ (Group VII), $362.6 \mathrm{mg} / \mathrm{dL}$ (Group VI), 430.7 $\mathrm{mg} / \mathrm{dL}$ (Group V), and $454.4 \mathrm{mg} / \mathrm{dL}$ (Group IV) compared to group III (563.4 mg/dL). Although, group II as the positive control $(228.5 \mathrm{mg} / \mathrm{dL})$ provided better decreased blood glucose levels compared to all treatment groups. 
Both flavonoids and tannins are suspected of playing a vital role in decreasing blood glucose levels. Flavonoids have antioxidant properties, thus protect pancreatic cells from reactive oxygen species (ROS). Also, flavonoids have hypoglycemic activity by inhibiting the $\alpha$ amylase enzyme and $\alpha$ glucosidase enzyme, which plays a role in breaking down carbohydrates into monosaccharides, thereby being absorbed by the intestine [19-24]. Flavonoid also stimulates the insulin-dependent AMPK (adenosine monophosphate-activated protein kinase) pathway, which analog to metformin. Metformin is the positive control used in this study [25].

On the other hand, tannins stimulate glucose and fat metabolism by providing antioxidant and anti-diabetic properties [26]. Besides, it also functions as a preservative or chelating agent that shrinks the intestinal epithelial membrane, thereby reducing the absorption of food juice as a result of inhibiting glucose intake and followed by the reduced blood sugar levels $[20,21,27]$.

\subsection{Histology of pancreatic organ.}

In diabetic model rats, there are morphological changes in pancreatic islets or islets of Langerhans, both of the number of cells and the shape islets cells [26]. The morphological change is involving necrosis and cell degeneration. Table 3 is presenting the number of islet cells.

Table 3. The number of islets cell in pancreatic organ of animals.

\begin{tabular}{l|c}
\hline Group & Number of cells \\
\hline Group I & 653 cells \\
\hline Group II & 604 cells \\
\hline Group III & 208 cells \\
\hline Group IV & 404 cells \\
\hline Group V & 600 cells \\
\hline Group VI & 650 cells \\
\hline Group VII & 658 cells \\
\hline
\end{tabular}

According to the histology of pancreatic organ conducted, the group I as the normal control was only showing healthy cells. The number of cells of group I was 653 cells, caused by the group I was not induced with STZ. Histology of Group I is presented in Figure 3(a). Group III, as the negative control, showed morphological changes of islet cells, which shrink, decrease cell number, and necrosis. The number of cells of Group III dropped to 208 cells. Figure 3(c) is showing morphological changes in group III.

Group II, as the positive control, was a group induced with STZ and was treated with metformin (Figure 3(b). It showed some necrosis and loss of the nucleus; meanwhile, the number of cells was increased to 604 cells. Metformin has similar activity as antioxidants, thus prevent pancreatic $\beta$ cell damage. Metformin captures or neutralizes the free radicals that repair tissue damage $[22,25]$.

The group IV was induced with STZ and treated with Olae (E. calophrys) stems ethanol extract dose of $100 \mathrm{mg} / \mathrm{kg} \mathrm{BW}$. The group showed some necrosis and loss of the nucleus. The number of cells also increased to 404 cells. The histology of group IV is shown in Figure 3(d). Group V was induced with STZ and treated with the extract dose of $150 \mathrm{mg} / \mathrm{kg} \mathrm{BW}$ was showing increasing number cells to 600 cells, yet still showing some necrosis and nucleus loss (Figure 3(e)). 


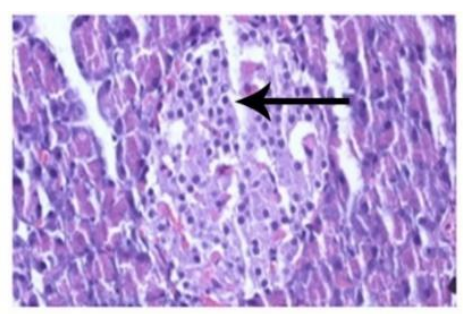

(a)

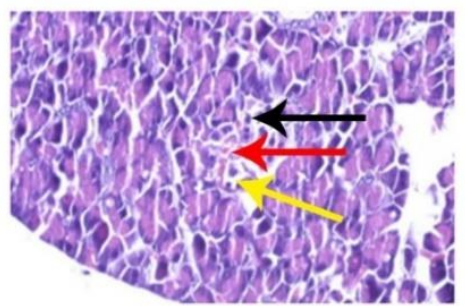

(c)

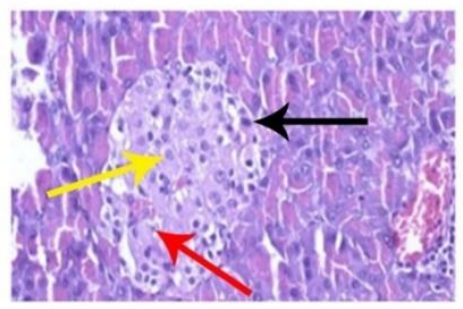

(e)

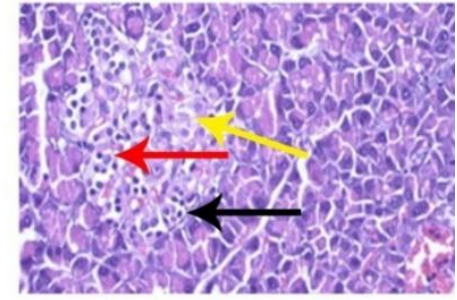

(b)

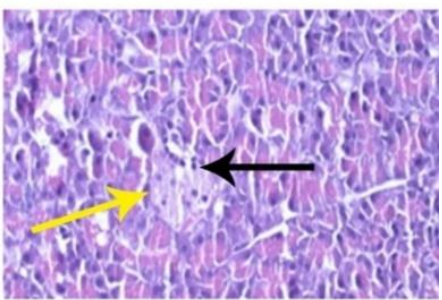

(d)

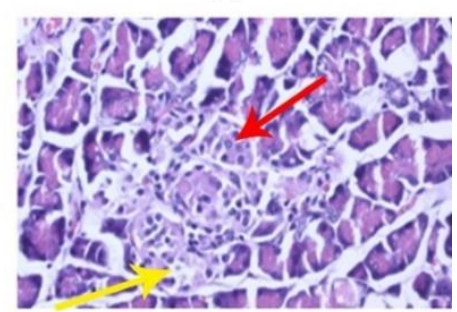

(f)

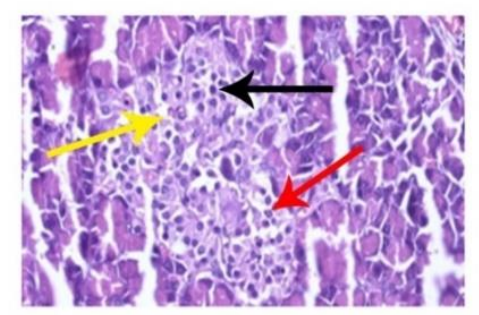

(g)

Legends:

$\longrightarrow$ : normal cell

$\longrightarrow$ : cell necrosis

: nucleus loss

Figure 3. Histology of islets of langerhans of rat (a) Group I; (b) Group II; (c) Group III; (d) Group IV; (e) group V; (f) Group VI; (g) Group VII.

Group VI (extract dose of $200 \mathrm{mg} / \mathrm{kg} \mathrm{BW}$ ) and VII (250 mg/kg BW) showed increased numbers of cells into 650 cells and 658 cells, respectively. Both groups showed similar results with Group IV and Group V), which still showed some necrosis and nucleus loss. However, the increase in the number of cells shows the protective and repair effect of Olae (E. calophrys) stems to extract. Both flavonoids and tannins contained in the extract are suspected responsible for the protective and repair effect. They are considered as natural antioxidants. Flavonoids are possibly decreasing oxidative stress by decreasing $\mathrm{H}_{2} \mathrm{O}_{2}$-induced oxidative damage and preserving pancreatic $\beta$-cell integrity [28-32].

\section{Conclusions}

Despite flavonoids, tannins, and terpenoids are present in Etlingera calophrys (K.Schum) A.D. Poulsen, or Olae stems ethanol extract, only both flavonoids and tannins are suspected in providing anti-diabetic effect. The extract decreases blood glucose levels in diabetic model rats and increasing the $\beta$-cells regeneration of islets of Langerhans, proved by pancreatic organ histology. 


\section{Funding}

The authors thank the Ministry of Research, Science, Technology, and Higher Education of the Republic of Indonesia for the Research grant scheme, a research grant scheme (Penelitian Dasar Unggulan Perguruan Tinggi 2019) for financial support with grant number 519a/UN29.20/PPM/2019.

\section{Acknowledgments}

This research has no acknowledgment.

\section{Conflicts of Interest}

The authors declare no conflict of interest.

\section{References}

1. Dipiro, J.T.; Talbert, R.L.; Yee, G.C.; Matzke, G.R.; Wells, B.G.; Posey, L.M. Pharmacotherapy: A Pathophysiologyc Approach. $7^{\text {th }}$ Edition, McGraw-Hill Companies, Inc. USA. 2018.

2. WHO [World Health Organization]. 2018. Available at: https://www.who.int/news-room/factsheets/detail/diabetes [Accessed 18 April 2020].

3. Omar, S.M.; Musa, I.R.; ElSouli, A.; Adam, I. Prevalence, risk factors, and glycaemic control of type 2 diabetes mellitus in eastern Sudan: a community-based study. Therapeutic Advances in Endocrinology and Metabolism 2019, 10, https://doi.org/10.1177/2042018819860071.

4. El-Gohary, Y.; Tulachan, S.; Wiersch, J.; Guo, P.; Welsh, C.; Prasadan, K.; Paredes, J.; Shiota, C.; Xiao, X.; Wada, Y.; Diaz, M.; Gittes, G. A Smad Signaling Network Regulates Islet Cell Proliferation. Diabetes 2014, 63, 224-36, https://doi.org/10.2337/db13-0432.

5. Oguntibeju, O.O. Type 2 diabetes mellitus, oxidative stress and inflammation: examining the links. International journal of physiology, pathophysiology and pharmacology 2019, 11, 45-63.

6. Hosseini, A.; Shafiee-Nick, R.; Ghorbani, A. Pancreatic beta cell protection/regeneration with phytotherapy J Brazilian Journal of Pharmaceutical Sciences 2015, 51, 1-16, https://doi.org/10.1590/S198482502015000100001

7. Wei, W.; Liu, Q.; Tan, Y.; Liu, L.; Li, X.; Cai, L. Oxidative Stress, Diabetes, and Diabetic Complications. Hemoglobin 2009, 33, 370-377, https://doi.org/10.3109/03630260903212175.

8. Khan, A.N.; Khan, R.A.; Ahmad, M.; Mushtaq, N. Role of antioxidant in oxidative stress and diabetes mellitus. Journal of Pharmacognosy and Phytochemistry 2015, 3.

9. Chan, E.W.C.; Lim, Y.Y.; Omar, M. Antioxidant and antibacterial activity of leaves of Etlingera species (Zingiberaceae) in Peninsular Malaysia. Food Chemistry 2007, 104, 1586-1593, https://doi.org/10.1016/j.foodchem.2007.03.023.

10. Fitrianita, A.; Yardi, M.A. Antihyperglycemic Effect of $70 \%$ Ethanolic Extract of Kecombrang (Etlingera elatior) Leaves on Alloxan-Induced Sprague Dawley Rats. Journal Ilmiah Farmasi 2018, 14, 9-16.

11. Pasaribu, F.; Sitorus, P.; Saiful, B.; Uji, E. Etanol Kulit Buah Manggis (Garcinia Mangostana L) Terhadap penurunan Kadar Glukosa Darah. Journal of Pharmaceutics and Pharmacology 2012, 1.

12. Sahidin, I.; Wahyuni, W.; Muh Hajrul, M.; Jabbar, A.; Imran, I.; Marianti, A.M. Evaluation of Antiradical Scavenger Activity of Extract and Compounds From Etlingera calophrys Stems. Asian Journal of Pharmaceutical and Clinical Research 2018, 11, https://doi.org/10.22159/ajpcr.2018.v11i2.22535.

13. Depkes, R.I. Suplemen II Farmakope Herbal Indonesia Edisi I. Departemen Kesehatan Republik Indonesia, Jakarta. 2011.

14. Harborne, J.B. Phytochemical Methods, A Guide to Modern Techniques of Plant Analysis. Chapman and Hall: London. 1973.

15. Muchtaridi, M.; Nuruljannah, H.; Laila, M.; Asih, N.; Moektiwardoyo, M.; Musfiroh, I.; Nur Hasanah, A. Determination Of Parameters Standardization Crude Drug And Extract Arabica Coffee Beans (Coffea Arabica L.). International Journal of Scientific \& Technology Research 2017, 4.

16. Sopiah, B.; Muliasari, H.; Yuanita, E. Phytochemical Screening and Potential Antioxidant Activity of Ethanol Ekstract of Green Leaves and Red Leaves Kastuba. Jurnal Ilmu Kefarmasian Indonesia 2019, 17, 27-33, https://doi.org/10.35814/jifi.v17i1.698.

17. Bandiola, T.M. Extraction and Qualitative Phytochemical Screening of Medicinal Plants: A Brief Summary. International Journal of Pharmacy 2018, 8, 137-143. 
18. Molehin, O.R.; Oloyede, O.I.; Adefegha, S.A. Streptozotocin-induced diabetes in rats: effects of White Butterfly (Clerodendrum volubile) leaves on blood glucose levels, lipid profile and antioxidant status. Toxicology Mechanisms and Methods 2018, 28, 573-586, https://doi.org/10.1080/15376516.2018.1479476.

19. Damasceno, D.C.; Netto, A.O.; Iessi, I.L.; Gallego, F.Q.; Corvinno, S.B.; Dallaqua, B.; Sinzato, Y.K.; Bueno, A.; Calderon, M.P.; Rudge, M.V.C. Streptozotocin-Induced Diabetes Models: Pathophysiological Mechanisms and Fetal Outcomes. BioMed Research International 2014, 2014, 1-11, https://doi.org/10.1155/2014/819065.

20. Coskun, O.; Kanter, M.; Korkmaz, A.; Oter, S. Quercetin, a flavonoid antioxidant, prevents and protects streptozotocin-induced oxidative stress and $\beta$-cell damage in rat pancreas. Pharmacological Research 2005, 51, 117-123, https://doi.org/10.1016/j.phrs.2004.06.002.

21. Mohammed, A.; Mohamed, E. The Promising Role of Plant Tannins as Bioactive Antidiabetic Agents. Current Medicinal Chemistry 2019, 26, $4852-4884$ https://doi.org/10.2174/0929867325666180605124256.

22. Proença, C.; Freitas, M.; Ribeiro, D.; Tomé, S.M.; Oliveira, E.F.T.; Viegas, M.F.; Araújo, A.N.; Ramos, M.J.; Silva, A.M.S.; Fernandes, P.A.; Fernandes, E. Evaluation of a flavonoids library for inhibition of pancreatic $\alpha$-amylase towards a structure-activity relationship. Journal of Enzyme Inhibition and Medicinal Chemistry 2019, 34, 577-588, https://doi.org/10.1080/14756366.2018.1558221.

23. Li, K.; Yao, F.; Xue, Q.; Fan, H.; Yang, L.; Li, X.; Sun, L.; Liu, Y. Inhibitory effects against $\alpha$-glucosidase and $\alpha$-amylase of the flavonoids-rich extract from Scutellaria baicalensis shoots and interpretation of structure-activity relationship of its eight flavonoids by a refined assign-score method. Chemistry Central Journal 2018, 12, https://doi.org/10.1186/s13065-018-0445-y.

24. El Omari, N.; Sayah, K.; Fettach, S.; El Blidi, O.; Bouyahya, A.; Faouzi, M.E.A.; Barkiyou, M. Evaluation of In Vitro Antioxidant and Antidiabetic Activities of Aristolochia longa Extracts. Hindadwi 2019, 2019, 1-9, https://doi.org/10.1155/2019/7384735.

25. Al-Ishaq, R.K.; Abotaleb, M.; Kubatka, P.; Kajo, K.; Büsselberg, D. Flavonoids and Their Anti-diabetic Effects: Cellular Mechanisms and Effects to Improve Blood Sugar Levels. Biomolecules 2019, 9, https://doi.org/10.3390/biom9090430.

26. Kunyanga, C.N.; Imungi, J.K.; Okoth, M.; Momanyi, C.; Biesalski, H.K.; Vadivel, V. Antioxidant and Antidiabetic Properties of Condensed Tannins in Acetonic Extract of Selected Raw and Processed Indigenous Food Ingredients from Kenya. Journal of Food Science 2011, 76, C560-C567, https://doi.org/10.1111/j.1750-3841.2011.02116.x.

27. Sun, C.; Zhao, C.; Guven, E.C.; Paoli, P.; Simal-Gandara, J.; Ramkumar, K.M.; Wang, S.; Buleu, F.; Pah, A.; Turi, V.; Damian, G.; Dragan, S.; Tomas, M.; Khan, W.; Wang, M.; Delmas, D.; Portillo, M.P.; Dar, P.; Chen, L.; Xiao, J. Dietary polyphenols as anti-diabetic agents: Advances and opportunities. Food Frontiers 2020, 1, 18-44, https://doi.org/10.1002/fft2.15.

28. Yabe, K.; Yamamoto, Y.; Suzuki, T.; Takada, S.; Mori, K. Functional and Morphological Characteristics of Pancreatic Islet Lesions Induced by Quinolone Antimicrobial Agent Gatifloxacin in Rats. Toxicologic Pathology 2018, 47, 35-43, https://doi.org/10.1177/0192623318809062.

29. Dehkordi, A.H.; Abbaszadeh, A.; Mir, S.; Hasanvand, A. Metformin and its anti-inflammatory and antioxidative effects; new concepts. 2019, 8, 54-61, http://dx.doi.org/10.15171/jrip.2019.11.

30. Ghorbani, A.; Rashidi, R.; Shafiee-Nick, R. Flavonoids for preserving pancreatic beta cell survival and function: A mechanistic review. Biomedicine \& Pharmacotherapy 2019, 111, 947-957, https://doi.org/10.1016/j.biopha.2018.12.127.

31. Gourlay, G.; Constabel, C.P. Condensed tannins are inducible antioxidants and protect hybrid poplar against oxidative stress. Tree Physiology 2019, 39, 345-355, https://doi.org/10.1093/treephys/tpy143.

32. Forni C, Facchiano F, Bartoli M, Pieretti S, Facchiano A, D'Arcangelo D, Norelli S, Valle G, Nisini R, Beninati S, Tabolacci C, Jadeja RN. Beneficial Role of Phytochemicals on Oxidative Stress and Age-Related Diseases. Biomed Res Int 2019, 8748253, https://doi.org/10.1155/2019/8748253. 